\title{
Exploring the Impact of Decision Making Culture on the Information Quality - Information Use Relationship: An Empirical Investigation of Two Industries
}

\author{
Aleš Popovič \\ University of Ljubljana, \\ Ljubljana, Slovenia
}

ales.popovic@ef.uni-lj.si

\author{
Andreja Habjan \\ Cardiff University, \\ Cardiff, UK
}

ahabjan@cardiff.ac.uk

\begin{abstract}
Information quality available to knowledge workers at various organizational levels within companies is of high priority in today's highly uncertain business environment. However, quality information is of little value to companies if it has not been used in decision making process. Previous works suggest a positive relationship between information quality and use, although there is limited empirical support to it. Moreover, the influence of additional organizational factors, such as decision making culture, has not been empirically tested in conjunction with information quality - information use relationship. The quantitative analysis carried out on data from two industries from Slovenian medium and large organizations shows a positive relationship of information quality on use of information. Yet, decision making culture has a suppressing effect on this relationship, thus bringing important implications for management and future research.
\end{abstract}

Keywords: Information quality, Information use, Decision making culture, Structural equation modeling

\section{Introduction}

Companies today are repeatedly recognizing that making quality decisions depends upon the quality of information available to support these decisions (Ge \& Helfert, 2008), thus making the provision of quality information the key to gaining a competitive advantage (Salaun \& Flores, 2001). Nevertheless, simply acquiring or possessing information is not directly related to company's performance, but it is rather the utilization of information (as reflected in the decisionmaking process) that is the key link between information acquisition and the company's performance (Souchon \& Diamantopoulos, 1996). If companies want the available quality information to

Material published as part of this publication, either on-line or in print, is copyrighted by the Informing Science Institute. Permission to make digital or paper copy of part or all of these works for personal or classroom use is granted without fee provided that the copies are not made or distributed for profit or commercial advantage AND that copies 1) bear this notice in full and 2) give the full citation on the first page. It is permissible to abstract these works so long as credit is given. To copy in all other cases or to republish or to post on a server or to redistribute to lists requires specific permission and payment of a fee. Contact Publisher@InformingScience.org to request redistribution permission. contribute to their performance, such information must be used to improve their decision-making (Raghunathan, 1999).

In the information systems (IS) field information quality and use have played an important role in defining success of various IS (DeLone \& McLean, 1992, 2003). Yet, research suggests there is insufficient data to support information quality - information use interrelation- 
ship of IS success at both individual and organizational level of analysis (Petter, DeLone, \& McLean, 2008).

The well established DeLone \& McLean IS Success Model, while comprehensive for measuring the success of various IS, it does not take into account additional dimensions regularly present in companies and impacting the relationships of DeLone \& McLean's IS Success Model constructs. One such important dimension is organizational culture (Gottschalk, 2007) and more specifically its sub dimension: the decision making culture.

With this research, focusing on organizational level, we aim to address the question of how does a company's decision making culture affect the use of available quality information in a company. The purpose of the paper is to explore the moderating effect of company's decision making culture on the relationship between information quality and use of information.

The outline of the paper is as follows: Section 2 introduces the fields of information quality, use of information and decision making culture. Section 3 aims to present the methodological framework for the study, while Section 4 deals with the testing of the proposed research model in different industries and the hypothesis. Section 5 concludes with a summary, a discussion of the main findings, and future work.

\section{Information Quality, Use, and Decision Making Culture}

In today's business environment quality information is a matter of primary interest. For more and more companies, information has increasingly become a critical resource and an asset in their business processes (Kirk, 1999). According to Stvilia, Gasser, Twidale, \& Smith (2007), for companies" "processes that depend on information, the quality of information is one of the key determinants of the quality of their decisions and actions". The contribution of high-quality information to companies is that it makes it easier to convert available information into knowledge, by helping to interpret and evaluate the information, by assisting the connection with prior knowledge, and by facilitating the application of the information to new contexts (Eppler \& Wittig, 2000).

While it is broadly recognized that information plays a critical role in the success of companies (C. W. Choo, 1996; Davenport, 2006), any information per-se acquired by decision-makers will deliver little impact on final performance of a company (Collins, 2001) if it is not actually used in the making of decisions (Davenport \& Beers, 1995; Howson, 2007). To contribute to company performance information must be good quality and support decisions in those organizational processes whose results add value to companies. Moreover, proper organizational culture, especially decision making culture, might reinforce the use of information provided by IS (Gottschalk, 2007; Wang \& Yeoh, 2009).

Our research focus is presented in Figure 1. In a previous study concerning business intelligence systems provision and use of information it has been has been shown a positive relationship between information quality and its use (Jaklič, Popovič, \& Coelho, 2011). We thus focus in this paper on the moderating impact of decision making culture on the relationship between information quality the use of information for decision making. 


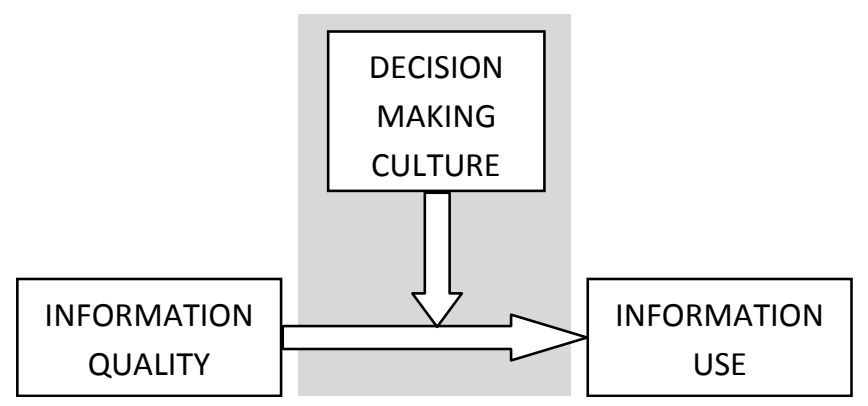

Figure 1: Research focus

The impact and use of information for decision-making has been extensively researched in the literature: Auster \& Choo (1994) inspected how managers in publishing and telecommunication industries use information to make day-to-day decisions and formulate longer term strategies, Wood \& Wright (1996) analyzed the impact of information usage on clinical decision-making, Winterman, Smith, \& Abell (1998) studied the impact of information usage on decision-making in government departments, Reid, Thomson, \& Wallace-Smith (1998) researched the impact of information utilization on corporate decision-making in the UK banking sector, Smith, Winterman, \& Abell (1998) researched this impact on the insurance sector whereas Bouchet, Hopkins, Kinnell, \& McKnight (1998) analyzed this impact on the pharmaceutical industry. In a case study of Singapore's managers, de Alwis \& Higgins (2001) investigated how information is used as a tool for management decision-making.

According to Badenoch, Reid, Burton, Gibb, \& Oppenheim (1995), any attempt to value information within a company has to be looked at in the context of the activity or decision it affects. The value of information depends on the information's relevance to the decision to be made, and on its precision, cost and reliability (Feldman \& March, 1981). Regarding the use of information in decision making processes literature suggests many potential beneficial effects for companies, such as: reducing uncertainty (Chengalur-Smith, Ballou, \& Pazer, 1999; Frishammar, 2003; Sjöberg, 2003), enhancing confidence (Al-Hakim, 2007; de Alwis \& Higgins, 2001), improving operational effectiveness (Nutt, 1993; Wijnberg, van den Ende, \& de Wit, 2002), reacting to business events (Badenoch, et al., 1995; C. W. Choo, 1996), performing proactive business planning, and supporting changes in corporate strategies and plans (Al-Mashari \& Zairi, 1999; Sen \& Taylor, 2007).

Decision making culture, a sub dimension of organizational culture, has previously been extensively researched. For this study, we regard decision making culture as those elements of a company's culture that influence its decision making and use of information. Ginman (1988) explored the connection between decision making culture and business performance, Chun Wei Choo, Bergeron, Detlor, \& Heaton (2008) explored the relationship between information culture and information use whereas Tierney (2008) provides a more theoretical view of the impact of culture on organizational decision making. Regardless of different fields of study of culture of decision making, a common understanding is that a more developed decision culture reinforces the use of quality information for decision making.

Based on the extensive literature review of the fields in question we put forward the following hypothesis: The relationship between information quality and the use of information is stronger the higher the level of decision making culture. 


\section{Research Methodology}

This research employed a survey to obtain data measuring participants' perceptions of available information quality, decision making culture, and perception about the use of information for decision making. The questionnaire was developed by building on the previous theoretical basis in order to ensure content validity. Pre-testing was conducted using a focus group involving academics interested in the field and semi-structured interviews with selected companies who were not interviewed later. This was also used to assure face validity. We used a structured questionnaire with 7-point Likert scales.

In order to assess information quality we adopted previously researched and validated indicators provided by Eppler (2006). We included 11 of the information quality criteria from Eppler's framework in the research instrument (Table 1).

Table 1: Indicators for constructs used in the study

\begin{tabular}{|c|c|c|}
\hline Construct & Label & Indicator (description) \\
\hline & & (1 = Strongly Disagree ... 7 = Strongly Agree) \\
\hline \multirow{11}{*}{ 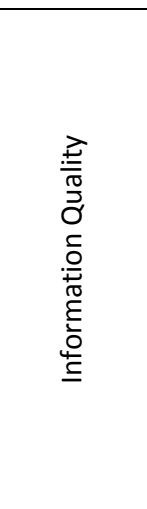 } & IQ1 & The scope of information is adequate (neither too much nor too little). \\
\hline & IQ2 & The information is not precise enough and not close enough to reality. \\
\hline & IQ3 & The information is easily understandable by the target group. \\
\hline & IQ4 & The information is to the point, without unnecessary elements. \\
\hline & IQ5 & The information is contradictory. \\
\hline & IQ6 & The information is free of distortion, bias or error. \\
\hline & IQ7 & The information is up-to-date and not obsolete. \\
\hline & IQ8 & The information provision corresponds to the user's needs and habits. \\
\hline & IQ9 & The information is processed and delivered rapidly without delay. \\
\hline & IQ10 & The background of the information is not visible (author, date etc.). \\
\hline & IQ11 & Information consumers cannot interactively access the information. \\
\hline \multirow{4}{*}{ 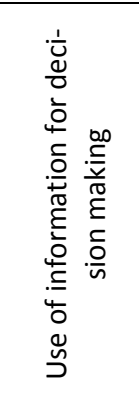 } & UI1 & $\begin{array}{l}\text { The available information within our company provides valuable input for assess business } \\
\text { processes against standards, for continuous process improvement programs, and for busi- } \\
\text { ness process change projects. }\end{array}$ \\
\hline & UI2 & $\begin{array}{l}\text { The available information within our company stimulates innovation in internal business } \\
\text { processes and external service delivery. }\end{array}$ \\
\hline & UI3 & $\begin{array}{l}\text { Information reduces uncertainty in the decision-making process, enhances confidence and } \\
\text { improves operational effectiveness. }\end{array}$ \\
\hline & UI4 & $\begin{array}{l}\text { Information enables us to rapidly react to business events and to perform proactive busi- } \\
\text { ness planning. }\end{array}$ \\
\hline \multirow{3}{*}{ 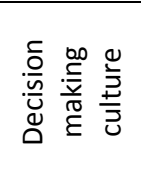 } & DC1 & Decision making process is well established and known to its stakeholders. \\
\hline & DC2 & $\begin{array}{l}\text { It is our organization's policy to incorporate available information into any decision making } \\
\text { process. }\end{array}$ \\
\hline & DC3 & We consider the provided information regardless of the type of decision to be taken. \\
\hline
\end{tabular}

For measuring use of information and decision making culture we used indicators available in the reviewed literature and those obtained from the pilot study. Since there were no previously validated indicators generally applicable to this study, we made some modifications to existing indicators and added ones derived from the pilot study (see Table 1). The pool of indicators for measuring the use of information and decision making culture corresponds to previously established uses of information and decision making culture respectively (see previous section). 
This study's target population were Slovenian medium and large size companies from financial/insurance industry and transport industry as they were listed in the registry of Slovenian Agency of Public Records and Related Services at the time of data gathering. The two industries under investigation were chosen mainly because of two reasons: 1) financial/insurance industry is one of the heaviest impacted industries since the beginning of the crises in 2008 and 2) transport industry shows best recovery rates in recent times. Empirical data for this research were collected by means of paper and Web-based survey. Questionnaires were addressed to senior managers estimated as having adequate knowledge about the quality of available information for decisionmaking and the use of information for decision-making. The final response rate was just below $12 \%$.

\section{Results}

We analyzed the gathered data using a form of structural equation modeling ('SEM'). For the estimation of the model we employed SEM-PLS (Structural Equation Models by Partial Least Squares) (Ringle, Wende, \& Will, 2007).

We first examined the reliability and validity measures for the constructs in the model. In the initial model not all reliability and convergent validity measures were satisfactory. Once the items that did not load satisfactorily had been removed, the model was rerun. In the final model all Cronbach's Alphas exceed the 0.70 threshold and were near 0.80 . Without exception, latent variable composite reliabilities are higher than 0.80 , showing a high internal consistency of indicators measuring each construct and thus confirming construct reliability. The average variance extracted ('AVE') is higher than 0.60, indicating that the variance captured by each latent variable is significantly larger than variance due to measurement error, and thus demonstrating a convergent validity of the constructs. Reliability and convergent validity of the measurement model was also confirmed by computing standardized loadings for indicators and bootstrap t-statistics for their significance. All standardized loadings exceed (or were very marginal to) the 0.70 threshold and they were found, without exception, significant at $0.1 \%$ significance level, thus confirming a high convergent validity of the measurement model. Detailed analysis of reliability and validity measures is presented in Table 2.

Table 2: Reliability and validity measures of the research model for both investigated industries

\begin{tabular}{|c|c|c|c|c|c|c|}
\hline Constructs & Indicators & \multicolumn{2}{|c|}{ Final model } & \multicolumn{3}{|c|}{ Estimates (final model) } \\
\hline & & Loadings & t-values & $\begin{array}{l}\text { Cronbach's } \\
\text { Alpha }\end{array}$ & $\begin{array}{l}\text { Composite } \\
\text { Reliability }\end{array}$ & $\begin{array}{l}\text { Average } \\
\text { Variance } \\
\text { Extracted }\end{array}$ \\
\hline \multirow{6}{*}{ Information Quality } & IQ1 & 0.7605 & 22.8401 & \multirow{6}{*}{0.8741} & \multirow{6}{*}{0.8224} & \multirow{6}{*}{0.6141} \\
\hline & IQ2 & 0.6769 & 11.5290 & & & \\
\hline & IQ3 & 0.7552 & 17.2144 & & & \\
\hline & IQ4 & 0.8251 & 35.6563 & & & \\
\hline & IQ5 & 0.8326 & 28.3961 & & & \\
\hline & IQ6 & 0.8401 & 28.5733 & & & \\
\hline \multirow{4}{*}{$\begin{array}{l}\text { Use of Information for Deci- } \\
\text { sion Making }\end{array}$} & UI1 & 0.8244 & 36.9850 & \multirow{4}{*}{0.7897} & \multirow{4}{*}{0.8636} & \multirow{4}{*}{0.6134} \\
\hline & UI2 & 0.7992 & 22.0546 & & & \\
\hline & UI3 & 0.7309 & 13.5531 & & & \\
\hline & UI4 & 0.7655 & 20.1977 & & & \\
\hline \multirow{3}{*}{ Decision Making Culture } & $\mathrm{DC} 1$ & 0.8140 & 23.7991 & \multirow{3}{*}{0.7794} & \multirow{3}{*}{0.8224} & \multirow{3}{*}{0.6083} \\
\hline & $\mathrm{DC} 2$ & 0.8253 & 25.2248 & & & \\
\hline & DC3 & 0.6941 & 8.9799 & & & \\
\hline
\end{tabular}

Note: All $\mathrm{t}$-values significant at the $.1 \%$ significance level $(\mathrm{N}=51, \mathrm{t}$ critical value $=3.291)$. 
To assess discriminant validity, the following two procedures were used: 1) a comparison of item cross loadings to construct correlations, and 2) determining whether each latent variable shares more variance with its own measurement variables or with other constructs. The first procedure for testing discriminant validity was to assess the indicator loadings on their corresponding construct. All the item loadings met the requirements of the first procedure in the assessment of discriminant validity. For the second procedure we compared the square root of the AVE for each construct with the correlations with all other constructs in the model. All the constructs show evidence for acceptable validity.

A bootstrapping with 1,000 samples has been conducted to test the hypothesized relationship between the constructs for both industries. As shown in Figure 1, the standardized path coefficients range from -0.139 to 0.519 while the $\mathrm{R}^{2}$ is strong, i.e. 0.659 for the endogenous construct. We can see that about $66 \%$ of the variance in use of information for decision making is explained by the influence of information quality and decision making culture. As indicated by the path loading information quality has a significant and positive effect on the use of information for decision making. Yet, decision making culture has significant negative effect on information quality - information use relationship $(\beta=-0.139, \mathrm{p}<0.05)$. This result thus does not confirm our theoretical expectation about our hypothesis. Figure 2 shows the results of testing the measurement model in the final run for transport industry whereas Figure 3 shows the results for participating companies from financial/insurance industry.

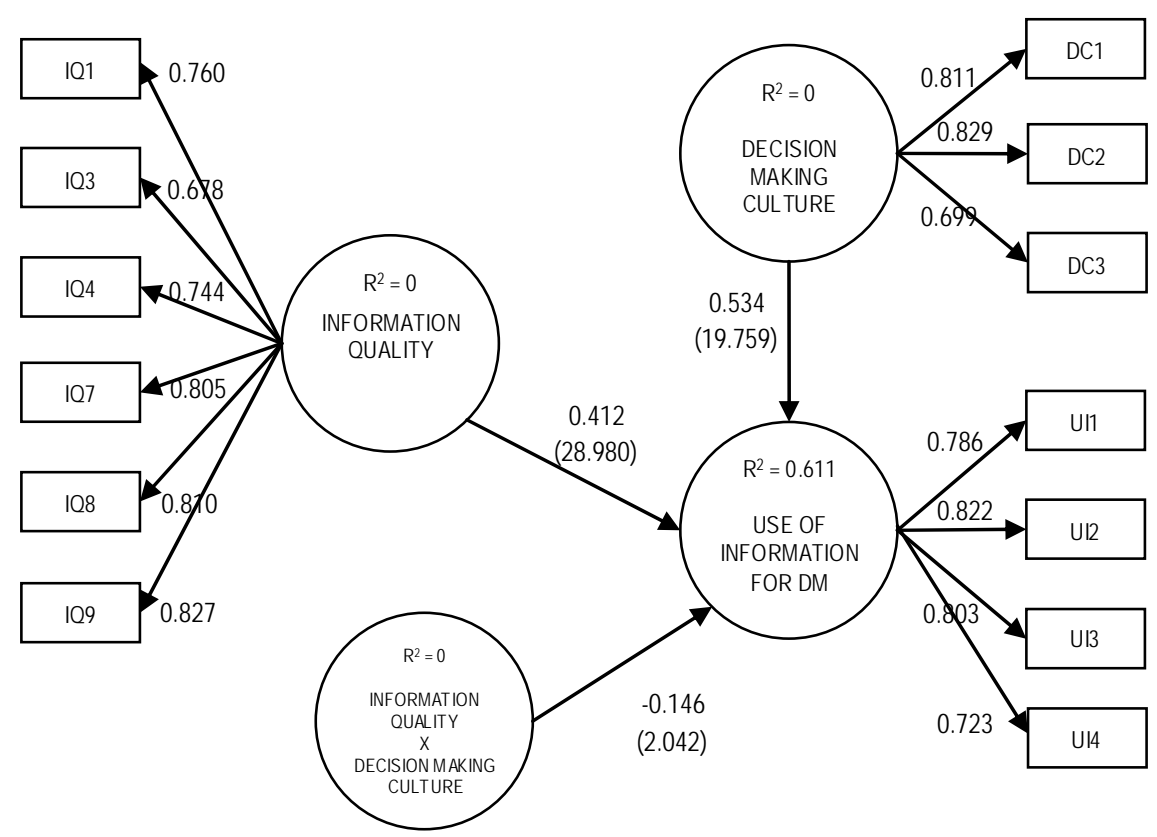

Figure 2: Final model for transport industry 


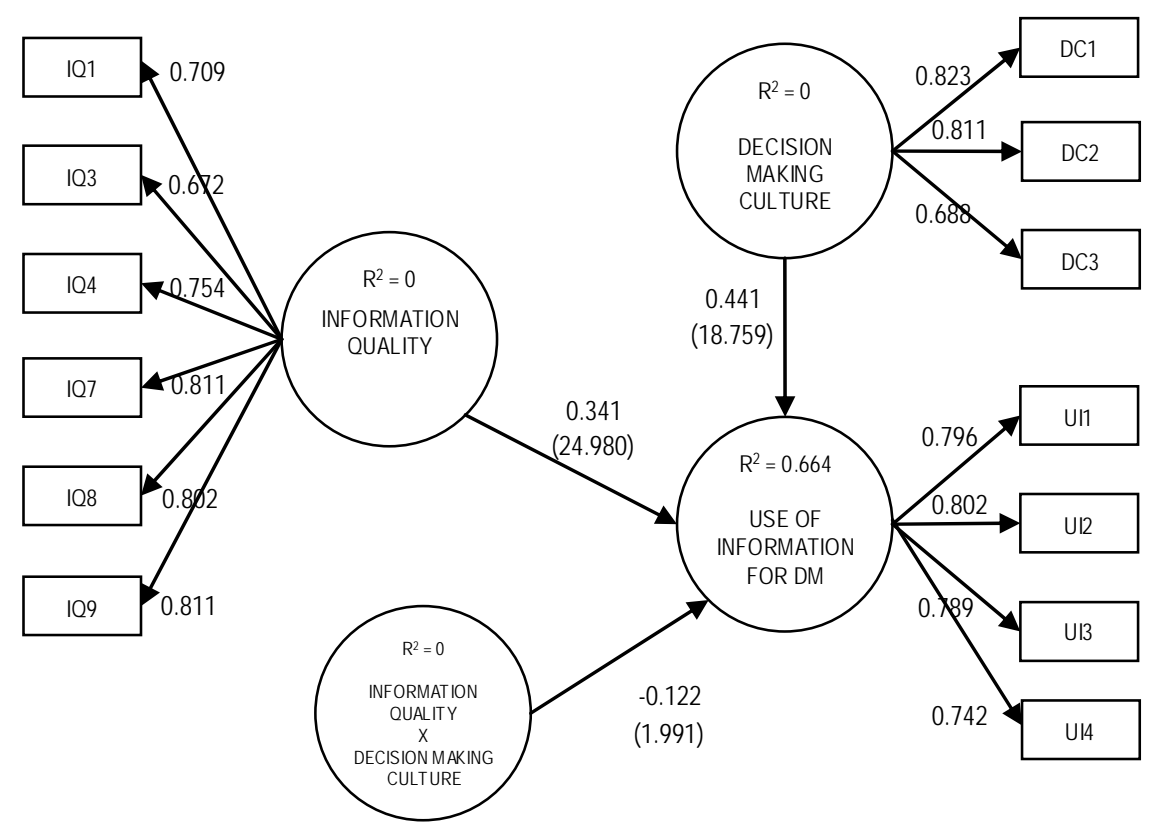

Figure 3: Final model for financial/insurance industry

\section{Discussion and Future Work}

Although not being of main focus of this research, this study confirms previous findings about the positive impact of information quality on the use of information. One of the important characteristics determining the degree to which information is used is, besides its quality, also the decision making culture of a company. This study analyses the impact of the decision making culture, as perceived by senior managers, on the relationship between information quality and the use of information for decision making. The use of information construct, as conceptualized in our model, reflects the role of information for decision-making in business processes. In decision-making, information reduces uncertainty, enables organizations to rapidly react to business events, and supports companies in making changes in corporate strategies, plans and performance indicators.

While it is widely recognized that information plays a critical role in the success of companies, information acquired by decision-makers will bear little impact on ultimate firm performance if it is not actually put to use in the making of decisions. Our hypothesis implies that improving the decision making culture always improves the use of information. However, the impact of decision making culture on the relationship between information quality and the use of information is negative; it suppresses the direct impact of information quality on the use of information. This implies that improving information quality will have a stronger effect on information usage in organizations with low levels of decision making culture. These findings have important implications for management: achieving higher levels of decision making culture (e.g. emphasizing the importance of fact based decisions, fostering the culture of information use, showing trust in available information) results in a weaker impact of information quality on the use of information.

Comparing the two industries under investigation both show a negative suppressing impact of decision making culture on the abovementioned relationship. Yet, it appears the transportation industry has a higher level of decision making culture (stronger impact) than the financial/insurance industry. Aligning these findings with the outcomes of tackling the country crises it appears as transportation companies with a higher established decision making culture are performing better than financial/insurance companies. 
Impact of Decision Making Culture on the Information Quality - Information Use Relationship

A limitation of this research is the cross-sectional nature of the data gathered. In fact, although the research and measurement model are well supported by theoretical assumptions and previous research findings, the ability to draw conclusions through our causal model would be strengthened with the availability of longitudinal data. For this reason, in future research other designs such as experimental and longitudinal designs should be tested. Moreover, future research could also focus on testing the proposed model on other industries and comparing results between them. Last but not least, it would also be useful to validate the proposed model in an international setting with comparable companies, since due to cultural differences we can expect different impacts in our model.

\section{References}

Al-Hakim, L. (2007). Information quality management: Theory and applications. Hershey, PA: Idea Group.

Al-Mashari, M., \& Zairi, M. (1999). BPR implementation process: An analysis of key success and failure factors. Business Process Management Journal, 5(1), 87-112.

Auster, E., \& Choo, C. W. (1994). How senior managers acquire and use information in environmental scanning. Information Processing \& Management, 30(5), 607-618.

Badenoch, D., Reid, C., Burton, P., Gibb, F., \& Oppenheim, C. (1995). The value and impact of information. In M. Feeney \& M. Grieves (Eds.), The value and impact of information. London; New Jersey: Bowker-Saur.

Bouchet, M. L., Hopkins, T., Kinnell, M., \& McKnight, C. (1998). The impact of information use on decision making in the pharmaceutical industry. Library Management, 19(3), 196-206.

Chengalur-Smith, I. N., Ballou, D. P., \& Pazer, H. L. (1999). The impact of data quality information on decision making: An exploratory analysis. IEEE Transactions on Knowledge and Data Engineering, 11(6), 853-864.

Choo, C. W. (1996). The knowing organization: How organizations use information to construct meaning, create knowledge and make decisions. International Journal of Information Management, 16(5), 329340 .

Choo, C. W., Bergeron, P., Detlor, B., \& Heaton, L. (2008). Information culture and information use: An exploratory study of three organizations. Journal of the American Society for Information Science and Technology, 59(5), 792-804.

Collins, J. (2001). Good to great: Why some companies make the leap ... and others don't. Harper Collins.

Davenport, T. H. (2006). Competing on analytics. Harvard Business Review, 84(1), 98-107.

Davenport, T. H., \& Beers, M. C. (1995). Managing information about processes. Journal of Management Information Systems, 12(1), 57.

de Alwis, S. M., \& Higgins, S. E. (2001). Information as a tool for management decision making: A case study of Singapore. Information Research, 7(1). Retrieved from http://informationr.net/ir/71/paper114.html

DeLone, W. H., \& McLean, E. R. (1992). Information systems success: The quest for the dependent variable. Information Systems Research, 3(1), 60-95.

DeLone, W. H., \& McLean, E. R. (2003). The DeLone and McLean Model of information systems success: A ten-year update. Journal of Management Information Systems, 19(4), 9-30.

Eppler, M. J. (2006). Managing information quality: Increasing the value of information in knowledgeintensive products and processes (2nd ed.). Springer. 
Eppler, M. J., \& Wittig, D. (2000). Conceptualizing information quality: A review of information quality frameworks from the last ten years. Paper presented at the Fifth Conference on Information Quality, University of St. Gallen.

Feldman, M. S., \& March, J. G. (1981). Information in organizations as signal and symbol. Administrative Science Quarterly, 26(2), 171-186.

Frishammar, J. (2003). Information use in strategic decision making. Management Decision, 41(4), 318326.

Ge, M., \& Helfert, M. (2008). A review of information quality research - Develop a research agenda. Paper presented at the International Conference on Information Quality.

Ginman, M. (1988). Information culture and business performance. IATUL Quarterly, 2(2), 93-106.

Gottschalk, P. (2007). Organizational culture as determinant of enterprise information systems use in police investigations. Enterprise Information Systems, 1(4), 443-455.

Howson, C. (2007). Successful business intelligence: Secrets to making BI a killer app (1st ed.). McGrawHill Osborne Media.

Jaklič, J., Popovič, A., \& Coelho, P. S. (2011). The impact of quality information provided by business intelligence systems on the use of information in business processes. In M. M. Cruz-Cunha, J. Varajão, P. Powell \& R. Martinho (Eds.), ENTERprise information systems (Volune 219, pp. 158-167), Berlin Heidelberg: Springer.

Kirk, J. (1999). Information in organisations: Directions for information management. Information Research, 4(3). Retrieved from http://informationr.net/ir/4-3/paper57.html

Nutt, P. C. (1993). The formulation process and tactics used in organizational decision making. Organization Science, 4(2), 226-251.

Petter, S., DeLone, W. H., \& McLean, E. R. (2008). Measuring information systems success: Models, dimensions, measures, and interrelationships. European Journal of Information Systems, 17(3), 236-263.

Raghunathan, S. (1999). Impact of information quality and decision-maker quality on decision quality: A theoretical model and simulation analysis. Decision Support Systems, 26(4), 275-286.

Reid, C., Thomson, J., \& Wallace-Smith, J. (1998). Impact of information on corporate decision making: the UK banking sector. Library Management, 19(2), 86-109.

Ringle, C. M., Wende, S., \& Will, A. (2007). SmartPLS 2.0 M3. University of Hamburg.

Salaun, Y., \& Flores, K. (2001). Information quality: Meeting the needs of the consumer. International Journal of Information Management, 21(1), 21-37.

Sen, B. A., \& Taylor, R. (2007). Determining the information needs of small and medium-sized enterprises: A critical success factor analysis. Information Research, 12(4). Retrieved from http://informationr.net/ir/12-4/paper329.html

Sjöberg, L. (2003). Intuitive vs. analytical decision making: Which is preferred? Scandinavian Journal of Management, 19(1), 17-29.

Smith, C., Winterman, V., \& Abell, A. (1998). The impact of information on corporate decision making in the insurance sector. Library Management, 19(3), 154-173.

Souchon, A. L., \& Diamantopoulos, A. (1996). A conceptual framework of export marketing information use: Key issues and research propositions. Journal of International Marketing, 4(3), 49-71.

Stvilia, B., Gasser, L., Twidale, M. B., \& Smith, L. C. (2007). A framework for information quality assessment. Journal of the American Society for Information Science and Technology, 58(12), 17201733.

Tierney, W. G. (2008). The impact of culture on organizational decision-making: Theory and practice in higher education. Sterling, Virginia, USA: Stylus Publishing. 
Wang, S., \& Yeoh, W. (2009, 6-7 June 2009). How does organizational culture affect IS effectiveness: A culture-information system fit framework. Paper presented at the Electronic Commerce and Business Intelligence, 2009. ECBI 2009. International Conference on.

Wijnberg, N. M., van den Ende, J., \& de Wit, O. (2002). Decision making at different levels of the organization and the impact of new information technology: Two cases from the financial sector. Group Organization Management, 27(3), 408-429.

Winterman, V., Smith, C., \& Abell, A. (1998). Impact of information on decision making in government departments. Library Management, 19(2), 110-132.

Wood, F., \& Wright, P. (1996). The impact of information on clinical decision making by General Medical Practitioners. Information Research, 2(1). Retrieved from http://informationr.net/ir/2-1/paper11.html

\section{Biographies}

Aleš Popovič is an Assistant Professor of Information Management at the Faculty of Economics at the University of Ljubljana and visiting professor at ISEGI - University Nova in Lisbon. He holds BS, MSC and Ph.D. degrees from the University of Ljubljana. His research focuses on business intelligence, information management, and business process management. He is the (co)author of numerous papers in national and international professional and scientific journals. He has collaborated in many applied projects in the areas of business process modelling, analysis, renovation and informatization and in the area of business intelligence.

Andreja Habjan is a member of the board of medium sized transport firm. She holds MSc and is a $\mathrm{PhD}$ candidate at Cardiff University. Her research focuses on road transportation, logistics, information and communication technologies, information management and business process management. She has led many applied projects in the area of quality assurance management, business process modelling and balanced scorecard implementation. 